\title{
Penjualan on-line berbasis media sosial dalam perspektif ekonomi Islam
}

\author{
M. Nur Rianto Al Arif \\ UIN Syarif Hidayatullah Jakarta \\ E-mail:agif08@gmail.com
}

Contemporary transactions along with the development of existing technologies have given rise to other forms of trading i.e. on-line trading. This paper aims to look at how the Islamic economic perspectives associated with on-line trading. The method used in this paper was library research. On-line trading had fulfilled the shariah principle, i.e. al-aqid, sighab, al-ma'qu'd alaih and the goal of the transaction. The transaction models that can be adopt in trading on line are bay' al-muräbahab and bay' al-saläm. Trading online had several advantage for buyer and seller, but trading on-line also had several problems. So, we must to had a strategy to minimize the various problems that may arise.

Dalam transaksi jual beli kontemporer seiring dengan perkembangan teknologi yang ada telah memunculkan bentuk penjualan lainnya yaitu penjualan on-line. Tulisan ini bertujuan untuk melihat bagaimanakah perspektif ekonomi Islam terkait dengan penjualan on-line. Metode yang digunakan dalam tulisan ini dengan pendekatan penelitian kepustakaan. Penjualan on-line telah memenuhi rukun akad dalam aturan syariah, seperti adanya penjual, pembeli, dan Sighah. Bentuk akad transaksi yang dapat diadopsi dalam penjualan on-line ialah bay' al-murābahah dan bay' al-saläm. Penjualan on-line memiliki beberapa manfaat baik dari sisi pembeli maupun penjual, namun penjualan on-line pun memiliki beberapa permasalahan. Sehingga harus dilakukan beberapa hal untuk meminimalisir berbagai permasalahan yang mungkin muncul tersebut.

Keywords: On-line trading; Aqad principle; Bay' al-murābaḥab; Bay' al-salām

\section{Pendahuluan}

Perkembangan teknologi telah memacu perubahan kebiasaan individu termasuk salah satunya dalam hal kebiasaan melakukan transaksi jual beli. Apabila dahulu yang dimaksudkan transaksi jual beli harus dilakukan secara tatap muka di mana terjadi peralihan barang secara langsung dari penjual kepada pembeli, yaitu pembeli harus bertemu dengan penjual di pasar nyata. 
ljtihad, Jurnal Wacana Hukum Islam dan Kemanusiaan, Volume 13, No. 1, Juni 2013: 33-48

Saat ini telah beralih kepada era di mana transaksi tidak lagi dilakukan secara tatap muka, melainkan sudah melalui media on-line. Tidak lagi harus terjadi pertemuan antara penjual dengan pembeli di pasar, melainkan cukup dengan menggunakan teknologi internet dan langsung terjadi transaksi antara penjual dan pembeli. Telah terdapat berbagai macam produk yang dijual tidak lagi melakukan penjualan secara tatap muka semata, melainkan sudah menggunakan teknologi untuk melakukan penjualan secara on-line.

Selain itu, dengan perkembangan teknologi yang sudah semakin modern, seiring dengan telah lahirnya berbagai teknologi baru seperti telepon pintar (smart-phone), tablet, dan berbagai gadget lainnya. Pada berbagai teknologi baru tersebut, konsumen dapat membeli berbagai fitur program dari pasar on-line yang terdapat pada berbagai teknologi tersebut baik secara gratis maupun berbayar.

Seiring dengan perkembangan teknologi dalam melakukan transaksi yang semakin berkembang ini, ternyata turut pula menimbulkan berbagai permasalahan. Beberapa permasalahan yang dapat muncul dalam transaksi on-line ialah (a) kualitas barang yang dijual, hal ini dikarenakan pembeli tidak melihat secara langsung barang yang akan dibeli. Penjual hanya melihat tampilan gambar dari barang yang akan dijual; (b) potensi penipuan yang sangat tinggi, di mana ketika pembeli sudah melakukan pembayaran namun barang tidak kunjung diantar kepada pembeli; (c) potensi gagal bayar dari pembeli, di mana ketika penjual sudah mengirimkan barang kepada pembeli namun pembayaran tidak kunjung dilakukan oleh pembeli.

Salah satu hal yang membedakan bisnis online dengan bisnis off line adalah proses transaksi (akad) dan media utama dalam proses tersebut. Akad merupakan unsur penting dalam suatu bisnis. Secara umum, bisnis dalam Islam menjelaskan adanya transaksi yang bersifat fisik, dengan menghadirkan benda tersebut ketika transaksi, atau tanpa menghadirkan benda yang dipesan, tetapi dengan ketentuan harus dinyatakan sifat benda secara konkret, baik diserahkan langsung atau diserahkan kemudian sampai batas waktu tertentu

Dengan melihat pada berbagai permasalahan di atas, maka tulisan ini bertujuan untuk mengkaji bagaimanakah perspektif ekonomi Islam dalam melihat perkembangan transaksi jual beli dengan menggunakan media on-line, serta apa saja yang harus dilakukan untuk meminimalisasi berbagai permasalahan di atas. 


\section{Pendekatan penelitian}

Pendekatan penelitian yang dipergunakan dalam tulisan ini adalah dengan melakukan penelitian kepustakaan (library research). Dalam penelitian kepustakaan, penelusuran pustaka yang dilakukan lebih dari sekedar menyiapkan kerangka penelitian atau proposal guna memperoleh penelitian sejenis, memperdalam kajian teoritis ataupun mempertajam metodologi. Penelitian kepustakaan dilakukan untuk memperoleh berbagai macam data yang diperlukan dalam penelitiannya (Zed, 2008: 1).

Pada tulisan ini penelitian kepustakaan dilakukan pertama dengan menelusuri berbagai literatur terkait dengan konsep akad dan jual beli dalam perspektif fiqh muamalah. Kemudian dari berbagai literatur tersebut dipergunakan untuk membahas bagaimanakah perspektif ekonomi Islam dalam memandang penjualan on-line terutama yang berbasis kepada media sosial. Hal ini bertujuan untuk memberikan penjelasan yang komprehensif mengenai model penjualan on-line berbasis media sosial yang saat ini sedang marak seiring dengan perkembangan teknologi internet.

\section{Konsep akad}

Dalam melakukan transaksi muamalah keseharian, salah satu hal penting yang harus diingat adalah masalah akad (perjanjian). Akad sebagai salah satu cara dalam memperoleh harta menurut syariat Islam yang dipergunakan pada kehidupan keseharian. Akad merupakan cara yang diridhai oleh Allah swt. dan harus ditegakkan isinya.

Kata akad berasal dari bahasa Arab al-'aqd dalam bentuk jamak disebut dengan al-uqūd yang berarti ikatan atau simpul tali (Ash-Shidiqy, 1984: 8). Menurut para ulama fiqh, kata akad didefinisikan sebagai hubungan antara ijab dan qabul sesuai dengan kehendak syariat yang menetapkan adanya pengaruh (akibat) hukum dalam objek perikatan. Akad diwujudkan pertama, dalam ijab dan qabul; kedua, sesuai dengan kehendak syariat; ketiga, adanya akibat hukum pada objek perikatan (Djamil, 2001: 247). Menurut etimologi, akad berarti ikatan antara dua perkara, baik ikatan secara nyata maupun ikatan secara maknawi, dari satu segi maupun dari dua segi (Zuhaily, 1989: 80).

Secara terminologi fiqh, akad didefinisikan dengan pertalian ijab (pernyataan melakukan ikatan) dan qabul (pernyataan penerimaan ikatan) sesuai dengan kehendak syariat yang berpengaruh kepada objek perikatan (Ghazaly, 2010: 51) 
ljtihad, Jurnal Wacana Hukum Islam dan Kemanusiaan, Volume 13, No. 1, Juni 2013: 33-48

Akad (ikatan, keputusan, atau penguatan) atau perjanjian atau transaksi dapat diartikan sebagai kemitraan yang terbingkai dengan nilai-nilai syariah. Dalam istilah fikih, secara umum akad berarti sesuatu yang menjadi tekad seseorang untuk melaksanakan, baik yang muncul dari satu pihak (seperti wakaf, talak, sumpah), maupun yang muncul dari dua pihak (seperti jual beli, sewa, wakalah, dan gadai) (Mardani, 2012: 72). Adapula yang mendefinisikan akad sebagai ikatan atas bagian-bagian tasharruf (pengelolaan) menurut syara' dengan cara serah terima (Suhendi, 2005: 46).

Secara khusus akad berarti kesamaan antara ijab (pernyataan penawaran/pemindahan kepemilikan) dan qabul (pernyataan penerimaan kepemilikan) dalam lingkup yang disyariatkan dan berpengaruh pada sesuatu (Ascarya, 2007: 35).

Dari berbagai pengertian di atas, dapat ditarik suatu kesimpulan umum bahwa yang dimaksud dengan akad ialah perikatan di antara kedua belah pihak yang dilakukan sesuai dengan syariat dan berakibat hukum pada objek yang menjadi perikatan. Hikmah diadakannya akad, antara lain (Ghazaly, 2010: 51) : 1). Adanya ikatan yang kuat antara dua orang atau lebih di dalam bertransaksi atau memiliki sesuatu. 2). Tidak dapat sembarangan dalam membatalkan suatu ikatan perjanjian, karena telah diatur secara syar’i. 3). Akad merupakan payung hukum di dalam kepemilikan sesuatu, sehingga pihak lain tidak dapat menggugat atau memilikinya.

Untuk sahnya suatu akad harus memenuhi hukum akad, adapun rukun akad tersebut adalah (Mardani, 2012: 72-73): a) Al-'Áqid atau pihak-pihak yang berakad adalah orang, persekutuan, atau badan usaha yang memiliki kecakapan dalam melakukan perbuatan hukum; b) Șighat atau perbuatan yang menunjukkan terjadinya akad berupa ijab dan qabul. c) Alma'qūd alaih atau objek akad. Objek akad adalah amwāl atau jasa yang dihalalkan yang dibutuhkan oleh masing-masing pihak. d). Tujuan pokok akad. Tujuan akad itu jelas dan diakui shara' dan tujuan akad itu terkait erat dengan berbagai bentuk yang dilakukan. Selain rukun, syarat akad juga harus terpenuhi agar akad itu sah, adapun syarat-syarat itu adalah (Mardani, 2012: 74-75).

Pertama, syarat adanya sebuah akad. Syarat adanya akad adalah sesuatu yang mesti ada agar keberadaan suatu akad diakui secara shara', syarat ini terbagi dua, yaitu syarat umum dan syarat khusus. Syarat umum adalah syarat yang harus ada pada setiap akad. Syarat 
umum ada tiga, yaitu: (1) syarat-syarat yang harus dipenuhi pada lima rukun akad; (2) akad itu bukan akad yang terlarang; (3) akad itu harus bermanfaat. Adapun syarat khusus adanya sebuah akad adalah syarat tambahan yang harus dipenuhi oleh suatu akad khusus seperti adanya saksi dalam akad. Namun adapula yang menambahkan syarat umum akad yang harus dipenuhi, sebagai berikut (Ghazaly, 2010: 51): (1) kedua orang yang melakukan akad cakap bertindak; (2) yang dijadikan objek akad dapat menerima hukumnya; (3) akad itu diijinkan oleh syara; (4) janganlah akad itu akad yang dilarang oleh shara'; (5) akad dapat memberikan faedah; (6) ijab itu berjalan terus, tidak dicabut sebelum terjadinya qabul, sehingga apabila orang yang berijab menarik kembali ijabnya sebelum qabul maka batallah ijabnya; (7) ijab dan qabul harus bersambung.

Kedua, syarat sah akad. Secara umum para fuqaha menyatakan bahwa syarat sahnya akad adalah tidak terdapatnya lima hal perusak sahnya dalam akad, yaitu: ketidakjelasan jenis yang menyebabkan pertengkaran, adanya paksaan, membatasi kepemilikan terhadap suatu barang, terdapat unsur tipunan, terdapat bahaya dalam pelaksanaan akad apabila dilanjutkan.

Ketiga, syarat berlakunya akad. Syarat ini bermasud berlangsungnya akad tidak tergantung pada izin orang lain. Syarat berlakunya suatu akad, yaitu: (1) adanya kepemilikan terhadap barang atau adanya otoritas untuk mengadakan akad, baik secara langsung ataupun perwakilan; (2) pada barang atau jasa tersebut tidak terdapat hak orang.

Keempat, syarat adanya kekuatan hukum suatu akad baru bersifat mengikat apabila ia terbebas dari segala macam hak khiyar (hak pilihan untuk meneruskan atau membatalkan transaksi.

\section{Konsep jual beli}

Dalam fikih Islam dikenal berbagai macam jual beli. Dari sisi objek yang diperjualbelikan, jual beli dibagi tiga, yaitu (Ascarya, 2008: 77): 1). Jual beli mutlaqah, yaitu pertukaran antara barang atau jasa dengan uang. 2). Jual beli șarf, yaitu jual beli antara satu mata uang dengan mata uang lain. 3). Jual beli muqayyadah, yaitu jual beli di mana pertukaran terjadi antara barang dengan barang (barter), atau pertukaran antara barang dengan barang yang dinilai dengan valuta asing. 
ljtihad, Jurnal Wacana Hukum Islam dan Kemanusiaan, Volume 13, No. 1, Juni 2013: 33-48

Dari sisi cara menetapkan harga, jual beli dibagi empat, yaitu (Ascarya, 2008: 78): 1). Jual beli musawamah (tawar menawar), yaitu jual beli biasa ketika penjual tidak memberitahukan harga pokok dan keuntungan yang didapatnya. 2). Jual beli amānah, yaitu jual beli di mana penjual memberitahukan modal jualnya (harga perolehan barang). Jual beli amānah ada tiga, yaitu: a) Jual beli murābaḥah, yaitu jual beli ketika penjual menyebutkan harga pembelian barang (termasuk biaya perolehan) dan keuntungan yang diinginkan; b) Jual beli muwada'ah (discount), yaitu jual beli dengan harga di bawah harga modal dengan jumlah kerugian yang diketahui, untuk penjualan barang atau aktiva yang nilai bukunya sudah sangat rendah; c) Jual beli tauliyah, yaitu jual beli dengan harga modal tanpa keuntungan dan kerugian; 3) Jual beli dengan harga tangguh, baiy' bi thaman ajil, yaitu jual beli dengan penetapan harga yang akan dibayar kemudian. Harga tangguh ini boleh lebih tinggi daripada harga tunai dan bisa dicicil. 4). Jual beli mu₹ayadah (lelang), yaitu jual beli dengan penawaran dari penjual dan para pembeli menawar, penawar tertinggi terpilih sebagai pembeli. Kebalikannya, jual beli munāqașah, yaitu jual beli dengan penawaran pembeli untuk membeli barang dengan spesifikasi tertentu dan para penjual berlomba menawarkan dagangannya, kemudian pembeli akan membeli dari penjual yang menawarkan harga termurah.

Kemudian dari sisi cara pembayaran, jual beli dibagi empat, yaitu: Pertama, Jual beli tunai dengan penyerahan barang dan pembayaran langsung. Kedua, Jual beli dengan pembayaran tertunda, bay' muajjal, yaitu jual beli dengan penyerahan barang secara langsung (tunai), tetapi pembayaran dilakukan kemudian dan bisa dicicil. Ketiga, Jual beli dengan penyerahan barang tertunda (deferred delivery), yang meliputi: a) Bay' al-salam, yaitu jual beli ketika pembeli membayar tunai di muka atas barang yang dipesan (biasanya produk pertanian) dengan spesifikasinya yang akan diserahkan kemudian. b) Bay' al-istithna, yaitu jual beli di mana pembeli membayar tunai atau bertahap atas barang yang dipesan (biasanya produk manufaktur) dengan spesifikasinya yang harus diproduksi dan diserahkan kemudian. Keempat, Jual beli dengan penyerahan barang dan pembayaran sama-sama tertunda.

\section{Penjualan on-line berbasis media sosial dalam ekonomi islam}

Penjualan on-line merupakan salah satu jenis transaksi jual-beli yang menggunakan media internet dalam penjualannya, yang saat ini paling banyak dilakukan ialah dengan berbasis 
kepada media sosial seperti facebook, twitter, dan berbagai media sosial lainnya untuk memasarkan produk yang mereka jual. Saat ini penjualan on-line merupakan salah satu jenis transaksi yang banyak dipergunakan dalam jual beli. Kemudian bagaimanakah perspektif ekonomi Islam dalam memandang penjualan on-line yang saat ini telah menjadi suatu hal yang sangat lumrah dilakukan dalam transaksi jual beli, terutama kepada penjualan on-line yang berbasis kepada media sosial.

Untuk menjawabnya, harus ditelusuri apakah dalam penjualan on-line telah memenuhi rukun-rukun akad yang sesuai dengan aturan fiqh. Sebagaimana yang diketahui ada empat rukun akad, yaitu: (a) ada pihak-pihak yang berakad; (b) sighbah atau ijab qabul; (c) Al-ma'qūd alaib atau objek akad; (d) tujuan pokok akad tersebut dilakukan.

Pihak-pihak yang berakad dalam penjualan on-line telah jelas, yaitu ada yang bertindak sebagai penjual dan ada yang bertindak sebagai pembeli. Șighah dalam penjualan on-line biasanya berupa syarat dan kondisi yang harus disetujui oleh konsumen. Syarat dan kondisi (term and conditions) yang harus disetujui dapat dipahami sebagai sebuah sighah yang harus dipahami baik oleh produsen maupun oleh konsumen.

Dalam hal penjualan on-line bentuk sighah yang dilakukan adalah dengan cara tulisan. Contohnya apabila kita membeli suatu program melalui telepon pintar (smartphone) akan ada pilihan bahwa konsumen telah membaca dan menyetujui aturan dan perjanjian yang dibuat. Syarat dan kondisi yang disetujui ini merupakan sighah yang harus dipahami baik oleh produsen maupun konsumen pada penjualan on-line. Begitu pula apabila kita melakukan transaksi dengan menggunakan media sosial, penjual harus menulis syarat dan kondisi apa saja yang terdapat dalam transaksi tersebut, sehingga terjadi keterbukaan antara penjual dan pembeli.

Kemudian rukun akad yang ketiga adalah objek akad dalam transaksi, dalam penjualan on-line objek akad harus jelas dan barang harus secara sempurna dimiliki oleh si penjual. Tidak boleh dalam penjualan on-line maupun penjualan tatap muka, barang belum dikuasai secara sempurna oleh si penjual. Hal ini bertujuan untuk menjaga agar tidak terjadi penipuan oleh si penjual. Penjual dalam penjualan on-line harus secara jelas menulis berbagai spesifikasi dari barang yang dijual termasuk kekurangan dari barang tersebut jika ada.

Rukun akad yang terakhir adalah tujuan dari akad tersebut harus sesuai dengan syariat. Sehingga penjualan on-line tidak boleh menjual barang yang tidak sesuai dengan aturan syariat. 
ljtihad, Jurnal Wacana Hukum Islam dan Kemanusiaan, Volume 13, No. 1, Juni 2013: 33-48

Misalkan menjual bayi dalam penjualan on-line seperti yang terjadi pada salah satu situs jual beli beberapa waktu yang lalu; atau; situs penjualan senjata atau narkoba. Bentuk contoh transaksi tersebut tidak diperkenankan, karena bertentangan dengan aturan syariat.

Terkait dengan rukun akad, penjualan on-line baik yang berbasis media sosial ataupun media lainnya diharamkan apabila memenuhi beberapa kriteria di bawah ini: Pertama, Sistemnya haram, contohnya ialah perjudian on-line. Kedua, Barang ataupun jasa yang ditawarkan oleh pembeli ialah barang atau jasa yang diharamkan syariat Islam. Ketiga, Terdapat pelanggaran perjanjian atau terjadinya unsur penipuan. Hal ini banyak terjadi pada penjualan on-line berbasis media sosial, di mana barang yang ditawarkan di media sosial seringkali berbeda dengan barang yang diterima oleh konsumen. Apabila terindikasi unsur penipuan, maka bentuk jual beli tersebut status hukumnya adalah haram.

Adapun bentuk akad transaksi jual beli yang dapat diadopsi dalam transaksi on-line ialah bay' al-murābaḥah (biasa disebut murabaḥah) dan bay' al-saläm (biasa disebut salam).

Bai' al-murabaḥah adalah jual beli barang pada harga asal dengan tambahan keuntungan yang disepakati. Dalam bay' al-murābaḥah, penjual harus memberi tahu harga produk yang dibeli dan menentukan suatu tingkat keuntungan sebagai tambahannya. Pada saat ini inilah produk akad jual beli yang paling banyak digunakan, karena inilah praktik yang paling mudah dalam implementasinya dibandingkan dengan produk pembiayaan yang lainnya. Adapun dasar hukum dari bay' al-murābaḥah:

"Orang-orang yang makan (mengambil) riba tidak dapat berdiri melainkan seperti berdirinya orang yang kemasukan syaitan lantaran (tekanan) penyakit gila. keadaan mereka yang demikian itu, adalah disebabkan mereka Berkata (berpendapat), Sesungguhnya jual beli itu sama dengan riba, padahal Allah Telah menghalalkan jual beli dan mengharamkan riba. orang-orang yang Telah sampai kepadanya larangan dari Tuhannya, lalu terus berhenti (dari mengambil riba), Maka baginya apa yang Telah diambilnya dahulu (sebelum datang larangan); dan urusannya (terserah) kepada Allah. orang yang kembali (mengambil riba), Maka orang itu adalah penghuni-penghuni neraka; mereka kekal di dalamnya" (QS Al Baqarah; 275).

\section{Sedangkan dari Hadis;}

"Dari Suhaib ar-Rumi r.a. bahwa Rasulullah saw. bersabda, "Tiga hal yang di dalamnya terdapat keberkahan: jual beli secara tangguh, muqaraddah (mudharabah), dan mencampur gandum dengan tepung untuk keperluan rumah bukan untuk dijual" (HR Ibnu Majab). 
Murabạ̣ah adalah akad jual beli barang dengan menyatakan harga perolehan dan keuntungan (marjin) yang disepakati oleh penjual dan pembeli. Akad ini merupakan salah satu bentuk natural certainty contracts, karena dalam murābạ̣ah ditentukan berapa required rate of profitnya (keuntungan yang ingin diperoleh). Karena dalam definisinya disebut adanya "keuntungan yang disepakati”, karakteristik murābạ̣ah adalah si penjual harus memberi tahu pembeli tentang harga pembelian barang dan menyatakan jumlah keuntungan yang ditambahkan pada biaya tersebut. Besaran harga jual harus sama-sama disepakati oleh kedua belah pihak, sehingga terjadi transaksi yang ridha sama ridha antara si penjual dan si pembeli.

Misalnya Ahsan membeli telpon genggam seharga 500 ribu rupiah, biaya-biaya yang dikeluarkan sebesar 50 ribu rupiah, maka ketika menawarkan telpon genggamnya, ia mengatakan: "saya jual telpon genggam ini 750 ribu rupiah, saya mengambil keuntungan 200 ribu rupiah.” Rukun dari akad murābạ̣ah yang harus dipenuhi dalam transaksi, yaitu: 1) Pelaku akad, yaitu bay' (penjual) adalah pihak yang memiliki barang untuk dijual, dan musytari (pembeli) adalah pihak yang memerlukan dan akan membeli barang; 2) Objek akad, yaitu mabi' (barang dagangan) dan thaman (harga); 3) Șighah, yaitu ijab dan qabul.

Syarat Bay' al-murābạ̣ah adalah: a) Penjual harus memberi tahu biaya modal kepada nasabah. b) Kontrak pertama harus sah sesuai dengan rukun yang ditetapkan. c) Kontrak harus bebas dari riba d) Penjual harus menjelaskan kepada pembeli bila terjadi cacat atas barang sesudah pembelian. e) Penjual harus menyampaikan semua hal yang berkaitan dengan pembelian. Secara prinsip, jika syarat (1), (4), atau (5) tidak dipenuhi, pembeli memiliki pilihan: melanjutkan pembelian seperti apa adanya; kembali kepada penjual dan menyatakan ketidaksetujuan atas barang yang dijual dan membatalkan kontrak.

Baiy' al-murābaḥah memberi banyak manfaat kepada penjual. Salah satunya adalah keuntungan yang muncul dari selisih harga beli dari penjual dengan harga jual kepada nasabah. Selain itu, sistem ini juga sangat sederhana, hal tersebut memudahkan penanganan administrasinya oleh penjual. Hal tersebutlah yang menjadi salah satu alasas mengapa akad bay' al-muräbaḥah dapat dipergunakan dalam penjualan on-line berbasis media sosial. Salah satu hal yang perlu dihindari oleh konsumen ialah apabila ada penjual yang menawarkan produk yang harganya jauh di bawah harga pasar. Misalkan ada pihak yang menawarkan penjualan telepon pintar ataupun tablet yang apabila kita beli di pasaran berkisar di atas lima 
ljtihad, Jurnal Wacana Hukum Islam dan Kemanusiaan, Volume 13, No. 1, Juni 2013: 33-48

juta kemudian ditawarkan hanya dengan harga satu juta saja. Perbedaan harga yang terlalu jauh dapat mengindikasikan kemungkinan terjadinya penipuan dalam transaksi penjualan tersebut. Namun apabila terjadi perbedaan harga yang masih dalam batas wajar, maka transaksi tersebut masih diperkenankan.

Beberapa hal yang dapat menjadi alasan mengapa seringkali penjualan on-line berbasis media sosial dapat lebih murah dibandingkan dengan penjualan langsung/konvensional: 1) Terjadinya penghematan biaya, karena alokasi dana yang awalnya dialokasikan untuk menyewa toko/kios dapat dialokasikan untuk menambah barangp 2) Jangkauan jaringan yang lebih luas; 3) Meminimalkan biaya promosi; 4) Pengaruh word of mouth.

Kemudian akad kedua yang mungkin dapat dipergunakan dalam penjualan on-line terutama yang berbasis kepada media sosial ialah bay' al-salam. Dalam pengertian sederhana, bay' alsalam berarti pembelian barang yang diserahkan di kemudian hari, sedangkan pembayaran dilakukan pada saat awal transaksi dilakukan. Barang yang diperjualbelikan belum tersedia pada saat transaksi dan harus diproduksi terlebih dahulu, seperti produk-produk pertanian dan produk-produk fungible (barang yang dapat diperkirakan dan diganti sesuai berat, ukuran dan jumlahnya) lainnya. Barang-barang non-fungible seperti batu mulia, lukisan berharga, dan lain-lain yang merupakan barang langka tidak dapat dijadikan objek salam. Risiko terhadap barang yang diperjualbelikan masih berada pada penjual sampai waktu penyerahan barang. Pihak pembeli berhak untuk meneliti dan dapat menolak barang yang akan diserahkan apabila tidak sesuai dengan spesifikasi awal yang disepakati.

Jual beli salam diperbolehkan oleh Rasulullah saw dengan beberapa syarat yang harus dipenuhi. Tujuan utama dari jual beli salam adalah untuk memenuhi kebutuhan para petani kecil yang memerlukan modal untuk memulai masa tanam dan untuk menghidupi keluarganya sampai waktu panen tiba. Setelah pelarangan riba, mereka tidak dapat lagi mengambil pinjaman ribawi untuk keperluan ini sehingga diperbolehkan mereka untuk menjual produknya di muka.

Saläm bermanfaat bagi penjual karena mereka menerima pembayaran di muka. Salam juga bermanfaat bagi pembeli karena pada umumnya harga dengan akad salam lebih murah daripada harga dengan akad tunai. Transaksi saläm sangat popular pada zaman Imam Abu Hanifah (80-150 H). Imam Abu Hanifah meragukan keabsahan kontrak tersebut yang mengarah kepada perselisihan. Oleh karena itu, beliau berusaha menghilangkan kemungkinan 
adanya perselisihan dengan merinci lebih khusus apa yang harus diketahui dan dinyatakan dengan jelas di dalam kontrak, seperti jenis komoditi, mutu, kuantitas, serta tanggal dan tempat pengiriman.

Ibnu Abbas meriwayatkan bahwa Rasulullah saw. datang ke Madinah di mana penduduknya melakukan salaf (salam) dalam buah-buahan (untuk jangka waktu) satu, dua dan tiga tahun. Beliau berkata,

"Barangsiapa yang melakukan salaf (salām), hendaknya ia melakukan dengan takaran yang jelas dan timbangan yang jelas pula, untuk jangka waktu yang diketahui”.

Diperbolehkannya salam sebagai salah satu bentuk jual beli merupakan pengecualian dari jual beli secara umum yang melarang jual beli forward sehingga kontrak salam memiliki syaratsyarat ketat yang harus dipenuhi, antara lain: 1) Pembeli harus membayar penuh barang yang dipesan pada saat akad saläm ditandatangani; 2) Saläm hanya boleh digunakan untuk jual beli komoditas yang kualitas dan kuantitasnya dapat ditentukan dengan tepat; 3) Salam tidak dapat dilakukan untuk jual beli komoditas tertentu atau produk dari lahan pertanian atau peternakan tertentu; 4) Kualitas dari komoditas yang akan dijual dengan akad saläm perlu mempunyai spesifikasi yang jelas tanpa keraguan yang dapat menimbulkan perselisihan. Semua yang dapat dirinci harus disebutkan secara eksplisit; 5) Ukuran kuantitas dari komoditas perlu disepakati dengan tegas; 6) Tanggal dan tempat penyerahan barang yang pasti harus ditetapkan dalam kontrak.; 7) Salam tidak dapat langsung dilakukan untuk barang-barang yang harus diserahkan langsung.

Namun demikian, terdapat juga syarat-syarat lain yang menjadi titik perbedaan antar mazhab. Syarat-syarat tersebut antara lain: Pertama, menurut mazhab Hanafi, komoditas yang akan dijual dengan akad saläm tetap tersedia di pasar semenjak akad efektif sampai saat penyerahan. Jika komoditas tersebut tidak tersedia di pasar pada saat akad efektif, salam tidak dapat dilakukan meskipun perkiraan komoditas tersebut akan tersedia di pasar pada saat penyerahan. Namun, ketiga mazhab lain (Syafii, Maliki dan Hambali) berpendapat bahwa ketersediaan komoditas pada saat akad efektif bukan merupakan syarat sahnya akad saläm. Yang penting bahwa komoditas tersebut tersedia pada saat penyerahan. Pendapat ini dapat diterapkan untuk kondisi sekarang. 
ljtihad, Jurnal Wacana Hukum Islam dan Kemanusiaan, Volume 13, No. 1, Juni 2013: 33-48

Kedua, menurut mazhab Hanafi dan Hambali, waktu penyerahan minimal satu bulan dari tanggal efektif. Jika waktu penyerahan ditetapkan kurang dari satu bulan, maka akad salam tidak sah. Mereka berarguman bahwa saläm diperbolehkan untuk memenuhi kebutuhan petani dan pedagang kecil sehingga kepada mereka seharusnya diberi kesempatan yang cukup untuk mendapatkan komoditas dimaksud. Imam Malik mendukung pendapat bahwa harus ada jangka waktu minimum tertentu dalam akad salam. Namun beliau berpendapat bahwa jangka waktunya tidak kurang dari 15 hari karena harga di pasar dapat berubah dalam waktu semalam.

Pendapat ini ditentang oleh beberapa ahli hukum fiqh yang lain, seperti Imam Syafii dan beberapa ulama Hanafi. Mereka mengatakan bahwa Rasulullah saw tidak menetapkan periode minimum sebagai syarat sahnya akad saläm. Satu-satunya syarat yang disebutkan dalam hadits adalah bahwa waktu penyerahan harus ditetapkan secara tegas sehingga tidak boleh ada batas waktu minimum. Para pihak dapat menetapkan tanggal penyerahan kapan saja mereka setuju bersama. Pendapat ini lebih sesuai untuk kondisi saat ini karena Rasulullah saw tidak menetapkan periode minimum.

Banyak orang yang menyamakan bay' al-saläm dengan ijon, padahal terdapat perbedaan besar di antara keduanya. Dalam ijon, barang yang dibeli tidak diukur atau ditimbang secara jelas dan spesifik. Demikian juga penetapan harga beli, sangat bergantung kepada keputusan sepihak si tengkulak yang seringkali sangat dominan dan menekan petani yang posisinya lebih lemah.

Adapun transaksi bay' al- saläm mengharuskan adanya dua hal berikut: a) Pengukuran dan spesifikasi barang yang jelas. Hal ini tercermin dari hadits Rasulullah yang diriwayatkan oleh Ibnu Abbas, "Barangsiapa melakukan transaksi salaf(salam), hendaklah ia melakukan dengan takaran yang jelas, timbangan yang jelas, untuk jangka waktu yang jelas pula." b) Adanya keridlaan yang utuh antara kedua belah pihak. Hal ini terutama dalam menyepakati harga.

Penjualan on-line terutama yang berbasis media sosial memiliki beberapa manfaat baik bagi pembeli maupun penjual, yaitu: a) Jam buka yang bersifat 24 jam, dengan menggunakan penjualan on-line penjual dapat menjual berbagai produk yang dimiliki 24 jam sehari. Hal ini berbeda dengan penjualan konvensional yang mungkin hanya memiliki waktu misalkan dari jam 9 pagi sampai dengan jam 10 malam. Sehingga hal ini akan memberi manfaat baik 
kepada penjual maupun kepada pembeli yang membutuhkan suatu produk; b) Lebih mudah dan lebih cepat untuk menemukan berbagai macam produk yang dibutuhkan oleh pembeli. c) Proses perbandingan harga yang mudah dan cepat dilakukan. Melalui penjualan on-line, calon pembeli dapat melakukan perbandingan harga pada berbagai macam barang yang ditawarkan dengan lebih mudah dan cepat; d) Mudah dilaksanakan oleh siapapun. Seringkali salah satu alasan orang enggan melakukan penjualan secara tatap muka ialah terkait dengan kurang percaya dirinya ia apabila berhadapan dengan pembeli secara langsung; e) Investasi yang lebih murah. Melalui penjualan on-line berbasis media sosial, penjual tidak perlu mengeluarkan dana investasi yang cukup besar untuk menyewa toko/outlet dan mempekerjakan karyawan.

Selain kelebihan yang dimiliki penjualan on-line terutama yang berbasis media sosial tersebut, terdapat beberapa kelemahan yang muncul dari penjualan on-line, yaitu: a) Pembeli tidak dapat melakukan cash and carry dari produk yang mereka beli; b) Pembeli tidak dapat memperhatikan detail dari produk yang ingin mereka beli, hal inilah yang menjadi salah satu keunggulan dari penjualan langsung (konvensional) di mana pembeli dapat memperhatikan detail barang dari produk yang akan mereka beli.

Terdapat beberapa permasalahan yang mungkin muncul dalam penjualan on-line berbasis media sosial yaitu: a) Kualitas produk yang tidak pasti. Karena calon pembeli tidak dapat memperhatikan detail dari produk yang akan mereka beli, dapat mungkin terjadi kualitas produk yang mereka beli jauh lebih rendah dibandingkan dengan ekspektasi kualitas yang diinginkan oleh calon pembeli; b) Potensi menipu dari penjual. Hal ini menjadi salah satu masalah yang mungkin muncul dalam media sosial, yaitu adanya penawaran barang yang hendak menipu pembeli misalkan dengan menawarkan seperangkat telepon pintar dengan potongan harga lebih dari 50 persen dibandingkan dengan harga pasar; c) Potensi menipu dari pembeli. Selain dari penjual, potensi menipu juga dapat muncul dari si calon pembeli.

Melihat pada permasalahan yang mungkin muncul dalam penjualan on-line tersebut, perlu dilakukan beberapa strategi yang dapat dilakukan untuk meminimalisir berbagai permasalahan tersebut, antara lain: a) Dalam penjualan on-line harus menampilkan secara utuh penampilan dan spesifikasi dari barang yang dijual. Oleh karenanya dalam situs jual beli, biasanya penampilan dari suatu produk yang dijual dapat dilihat dari berbagai sisi; b) Hak pilih (khiyär) 
ljtihad, Jurnal Wacana Hukum Islam dan Kemanusiaan, Volume 13, No. 1, Juni 2013: 33-48

bagi pembeli jika ternyata barang yang diterima berbeda spesifikasinya dengan yang ditampilkan pada iklan, termasuk adanya garansi pada barang-barang seperti elektronik dan komputer. c) Menggunakan media pembayaran yang aman, hal ini bertujuan untuk melindungi baik dari sisi pembeli maupun penjual.

Dengan melihat berbagai penjelasan di atas, penjualan on-line merupakan hal yang dapat diperkenankan sesuai dengan kemajuan dan perkembangan teknologi, mengingat banyaknya manfaat yang dapat diperoleh dari model penjualan seperti ini. Namun yang perlu diingat baik oleh penjual maupun pembeli ialah prinsip kehati-hatian untuk meminimalisir kemungkinan terjadinya penipuan baik dari sisi penjual maupun dari sisi pembeli.

Secara umum penjualan on-line berbasis media sosial oleh penjual dapat dipergunakan bagi:

Satu-satunya metode penjualan yang dilakukan oleh si penjual. Penjual hanya memanfaatkan penjualan on-line berbasis media sosial sebagai ujung tombak penjualan yang dilakukan. Dalam hal ini, penjual memanfaatkan berbagai media sosial yang dipergunakan untuk menjual secara on-line berbagai produk yang ingin ditawarkan kepada para calon pembeli potensial. Apabila penjual hanya memanfaatkan media sosial sebagai satu-satunya metode penjualan, maka si penjual harus rajin untuk selalu melakukan pembaharuan ataupun memposting ulang atas berbagai display yang ditawarkan, hal ini agar calon pembeli potensial dapat terus ingat dengan produk yang ditawarkan oleh si penjual.

Penjualan on-line sebagai salah satu penunjang metode penjualan oleh penjual. Pada hal yang kedua ini, penjual memiliki toko/outlet fisik yang dipergunakan untuk display produkproduk yang ditawarkan sehingga calon pembeli yang kurang yakin dengan tampilan di media sosial dapat langsung mengunjungi toko/outlet fisik, penjualan on-line sebagai salah satu penunjang ataupun metode penjualan yang dipergunakan untuk memperluas jangkauan jaringan.

\section{Penutup}

Perkembangan transaksi jual beli kontemporer, tidak lagi semata mengandalkan penjualan dengan tatap muka. Transaksi jual beli kontemporer seiring dengan perkembangan teknologi, telah memunculkan bentuk penjualan lainnya yaitu penjualan on-line. Penjualan on-line merupakan 
salah satu bentuk penjualan yang memanfaatkan teknologi seperti telepon pintar, tablet, gadget, dan yang memanfaatkan jaringan internet.

Penjualan on-line telah memenuhi rukun akad dalam aturan syariah, yaitu (a) adanya penjual dan pembeli; (b) șighah atau ijāb qabūl telah terpenuhi di mana konsumen harus menyetujui syarat dan kondisi yang tertulis jika proses transaksi ingin dilanjutkan; (c) objek akad dalam penjualan on-line harus jelas spesifikasinya; (d) tujuan akad tidak boleh bertentangan dengan syariat.

Bentuk akad transaksi yang dapat diadopsi dalam penjualan on-line ialah bai al-murabạ̣ah dan bay al-saläm. Bay' al-muräbaḥah adalah jual beli barang pada harga asal dengan tambahan keuntungan yang disepakati. Sedangkan bay' al-salam berarti pembelian barang yang diserahkan di kemudian hari, sedangkan pembayaran dilakukan pada saat awal transaksi dilakukan

Terdapat beberapa kelebihan dari penjualan on-line, yaitu: (a) jam buka yang dapat 24 jam; (b) lebih mudah dan cepat dalam mencari dan menjual barang; (c) proses perbandingan harga yang mudah dan cepat; (d) mudah dilaksanakan oleh siapapun; (e) investasi yang lebih murah. Selain kelebihan, terdapat pula kelemahan yang terdapat pada penjualan on-line, yaitu: (a) model pembelian yang tidak dapat cash and carry; (b) pembeli tidak dapat memperhatikan detail dari produk yang ditawarkan oleh penjual.

Terdapat beberapa permasalahan yang mungkin muncul dalam penjualan on-line yaitu: (a) kualitas produk yang tidak pasti; (b) potensi menipu dari penjual; (c) potensi menipu dari pembeli, maka dalam penjualan on-line perlu dilakukan beberapa hal yang dapat dilakukan untuk meminimalisir berbagai permasalahan tersebut, antara lain: (a) Dalam penjualan on-line harus menampilkan secara utuh penampilan dan spesifikasi dari barang yang dijual; (b) Harus ditambah dengan akad tambahan berupa adanya hak pilih (khiyar) bagi pembeli jika ternyata barang yang diterima berbeda spesifikasinya dengan yang ditampilkan pada iklan; (c) Menggunakan media pembayaran yang aman, hal ini bertujuan untuk melindungi baik dari sisi pembeli maupun penjual. 
ljtihad, Jurnal Wacana Hukum Islam dan Kemanusiaan, Volume 13, No. 1, Juni 2013: 33-48

\section{Daftar pustaka}

Antonio, M. Syafii. Bank Syariah: Teori dan Praktik. Jakarta: Gema Insani Press, 2001.

Al Arif, M. Nur Rianto. Dasar-Dasar Ekonomi Islam. Surakarta: Era Intermedia, 2011.

Al-Bugha, Musthafa Dib. Buku Pintar Transaksi Syariah. Jakarta: Hikmah, 2010

Al-Zuhaily, Wahbah. Al Fiqh Al-Islam wa Adillatuh, juz IV. Damsyik: Dar Al Fikr, 1989.

Ascarya. Akad dan Produk Bank Syariah. Jakarta: RajaGrafindo Persada, 2007.

Ash-Shidiqi, TM Hasbi. Pengantar Fiqh Muamalah. Jakarta: Bulan Bintang, 1984

As-Sa'di, Syekh Abdurrahman, et.al. Fiqh Jual Beli, alihbahasa Abdullah. Jakarta: Senayan Publishing, 2008.

Ath-Thayyar, Abdullah bin Muhammad, et.al. Ensiklopedi Fiqih Muamalah dalam Pandangan 4 Mazhab (terj). Yogyakarta: Maktabah Al-Hanif, 2009

Mahkamah Agung. Kompilasi Hukum Ekonomi Syariah. Jakarta: Mahkamah Agung Republik Indonesia.

Mardani. Fiqh Ekonomi Syariah. Jakarta: Kencana, 2012.

Nasroen, Harun. Fiqh Muamalah. Jakarta: Gaya Media Pratama, 2007.

Nawawi, Ismail. Fikih Muamalah Klasik dan Kontemporer. Bogor: Ghalia Indonesia, 2012

Rahardjo, M. Dawam. Islam dan Transformasi Sosial-Ekonomi. Jakarta: Lembaga Studi Agama dan Filsafat, 1999.

Suhendi, Hendi. Fiqh Muamalah. Jakarta: Rajawali Pers, 2008.

Syafei, Rahmat. Fiqh Muamalah. Bandung: Pustaka Setia, 2001.

Yafie, Ali. Fiqh Perdagangan Bebas. Bandung: Teraju, 2003.

Zed, Mestika. Metode Penelitian Kepustakaan. Jakarta: Obor Indonesia, 2008. 